\title{
Interpreting the Bible in the 'new' South Africa: Remarks on some problems and challenges
}

D J Human

Department of Biblical Studies (Sec B)

University of Pretoria

\begin{abstract}
Interpreting the Bible in the 'new' South Africa

The Bible plays an important role in South African society. The interpretation of this book within or outside the Christian community has become an increaslingly major source of debate. It has been used and misused in several spheres of society. This article does not intend providing an extensive and composite picture of the problems and character of biblical hermeneutics. Nor will it attempt to elaborate on or explain the origins, development and influences of all the different hermeneutical approaches. Rather, it poses to be an introduction to a few of the problem(s) encountered in the attempt to understand the Bible, especially in terms of the 'new' South Africa. Within the framework of this scope, remarks will be made regarding the challenges involved in interpreting the Bible, the role of the interpreter in the interpretation process, the varied forms of literature to be found in Scripture, and in the last instance, to take cognisance of a few methodological approaches to the text analysis of the Bible.
\end{abstract}

\section{INTRODUCTION}

South Africans are living in a country, which - religiously - is predominantly Christian. Whether Christianity outnumbers other religions and beliefs in South Africa or not, the Christian community with its variety of faces, emphases and attitudes, has

* This paper was read at the annual congress of the South African Biblical Studies Society in Bloemfontein on 18 May 1996. The theme of the congress was 'Interpreting the Bible for the New South Africa'. I dedicate my paper to a dear friend and colleague, Professor J J Engelbrecht. We have been working together closely in the Department of Biblical Studies at the University of Pretoria since 1992. We have shared memorable moments in the academic world, and he has been a true mentor. I thank him for that. I wish him a healthy future with his wife.

* The term 'New South Africa' is no official term, but it is in the spirit of the above-mentioned congress theme an indication of a democratic post-apartheid time period in South Africa. 
nevertheless exerted a major influence on the South African society for the past few decades. On the political, social, economic and other scenes, Christians have not been silent regarding their convictions. Political, educational and moral issues are usually presented as being founded on and motivated by biblical interpretation, often with the confident assumption that these biblical interpretations are found on divine authority.

Generally speaking, the history of biblical interpretation in the South African society or context reflects how the Bible was used, for example, to either legitimize party political policy by a certain group of this Christian community or to demonize the same policy by another faction of this community. Several groups have argued with conviction and acclamation that their viewpoints represent God's will for their situation and circumstances. This not only applies to the apartheid/anti-apartheid struggle in South Africa. In the same way other social, moral and ethical issues have been treated and are still being dealt with. People use the Bible for example to condemn abortion and lottery, while others extract principles from the same Bible which allow people the right for abortion on request, the right to lottery, the right for civil obedience or disobedience. Innumerable examples can be added: Pro- and contra arguments are formulated on questions regarding land reforms, political restitution, RDP programs, the right to strike, homosexuality and extra-marital relationships, the paying of taxes and television licences, church unity, the celebration of a Sunday, et cetera.

What has been sketched here is merely a situation analysis and not an assessment of what is right or what is wrong. From this given explication, the question arises whether people use or rather misuse the Bible for their own purposes, for example, to legitimize their own position in life and in society or to claim, intentionally or in ignorance, divine authority for their religiously substantiated policies, statements or viewpoints.

The Bible interpreter (whether a specialist or not) has a role to play, notwithstanding the ideology and prejudices behind him and his interpretations. However, people in the South African society mostly (but not in all instances) tend to interpret the Bible biblisistically and fundamentalistically. This means that the Bible is interpreted directly and literally from the biblical text and applied to any given life situation without taking the historical and literary contexts of the those texts seriously or even into consideration. In this way the Bible becomes a book of witchcraft or a magic textbook from which magic formulas are taken to solve problems, to settle difficult situations or to clear up uncertainties. The world behind the text, the world within the text and the world in front of the text are totally ignored (Barton 1984:198ff). In the view of the Bible scientist, the eleventh commandment, namely, to interpret the text within context, is seriously trespassed. 
The rather embarrassing situation exists that pious and godfearing believers sometimes commit this hermeneutical sin in ignorance. Especially they, but also other Bible readers should be made aware of the problems, the challenges and the approaches inherent in the biblical understanding processes. People should be saved from the disillusionment of being misled by others, who, obsessed with powerlust and selfish hidden agendas, guide their good, believing followers easily and smoothly through the streets of the political, social, economical, moral and religious life spheres with vehicles of divine authorized certainties and truths. People in the New South Africa should thus, hermeneutically spoken, be made literate, enabling them to read the Bible responsibly in order to apply the interpreted biblical norms to their lives.

The awareness of and the understanding for different interpretation models and the interpretation process itself should not only create an attitude of openness and tolerance amongst Bible readers and believers about their differences, but should rather stimulate differential thought regarding biblical perspectives as well as the selfconfidence of the ordinary Bible reader to formulate his/her own opinion on any issue of faith. With the different hermeneutical keys in hand, the interpreter will not only be able to unlock and discover the variety of jewel chambers in the Bible, but he/she will develop the necessary hermeneutical skills of suspicion and retrieval.

In the interpreter's growing understanding of the hermeneutical process, the question about what the biblical truth (what is right or what is wrong) on certain faith issues is, will attain peripheral value and the question will make room for the aha-experience which is substantiated on the insight that there are several perspectives on biblical truth. By gaining this insight, the ordinary Bible reader will discover the misterium (mystery) of the variegated God, whose voice echoes through the frozen deposit of biblical texts, which reflect the faith experiences of ancient faith communities. The excitement of this aha-experience will lay claim to the faith of one's second naivety.

This article has no intention of providing an extensive and complete picture of the problems and character of biblical hermeneutics. Nor has it the goal to elaborate on or explain the origins, development and influence of all the different hermeneutical approaches. It rather poses to be an introduction to a few problem(s) encountered when trying to understand the Bible, also in the New South Africa. Within the scope of this framework, remarks will be made on the challenges of interpreting the Bible, the role of the interpreter in the interpretation process, the varied forms of literature to be found in Scripture, and in the last instance, cognisance will be taken of a few methodological approaches to the text analysis of the Bible. 


\section{CHALLENGES FOR BIBLICAL INTERPRETATION}

When the Bible reader or interpreter reads the biblical texts in order to determine significance for whatever purpose, he/she is confronted with a few challenges. Several difficulties have to be taken into consideration during the understanding process.

Firstly, the Bible is a literary product of the ancient world. Both the Old and New Testaments represent different worlds and worldviews respectively. The modern interpreter immediately faces the distance and divergence between two and even more different civilisations. The ancient world of the Bible where the earth was founded on pillars, is cetainly not identical to the modern world where nuclear weapons, cell telephones, test-tube babies, space shuttles, heart transplantations, aids and fax machines are ordinary commodities. His first challenge, therefore, is to bridge the large gaps (garstige Grabe) of time, culture, geography and language.

Not only do centuries exist between the written texts and the modern mind of today, but long periods of time also divide the actual biblical events. This applies to the time when events took place and the time when they were recorded in their written and theologically interpreted form as we have it today. The book Isaiah, which actually consists of three books, namely Proto-, Deutero- and Trito-Isaiah is a case in point. Each book not only addressed the separate communities of the pre-exilic, exilic and post-exilic periods consecutively, but a later redactor must have composed all three books for a later post-exilic community. This context, however, is centuries removed from the years ca. $750 \mathrm{BC}$ when the person Isaiah prophesied to the 8th century Jerusalem (Judean) community. All these contexts are frozen in and to be distinguished from one text, namely the book Isaiah. This necessarily reflects a difference in social, cultural, political and religious perspectives, which have to be distinguished and recognized by the Bible interpreter.

Sometimes biblical texts were newly reinterpreted in view of new circumstances. Fresh additions were then made. We know that the book Hosea originated in the Northern Kingdom. After the Assyrian exile (ca.722 BC), the theological traditions of the North were taken down to the Southern Kingdom, where fresh theological interpretations in view of the new context were made. Hosea 3:5 reads: 'But the time will come when the people of Israel will once again turn to the Lord'. Then we find the later addition 'and to a descendent of David their king'. People of the Southern Kingdom applied the text of the Northern Kingdom to their own situation in the south. The same can be said for the even later wisdom proverb in Hosea 14:10, which was probably added by a wisdom teacher. In order to understand these and other texts, the Bible interpreter should take note of and distinguish between the different worlds in one text, before he distracts the significance of those texts into his (even different) world. 
During the interpreting process, it becomes clear that certain customs, beliefs and practices are unknown or strange to the mind of modern society. The 'exchange of a sandal' (Ruth 4:6-8), the 'headcovering' (1 Cor 11:4-16) or 'ceremonial washing' of he Pharisees (Mk 7:3-5) are typical examples. Studies of the social and cultural background or of the Mediterranean and Ancient Near Eastern worlds are inevitable for biblical understanding. The interpreter, nevertheless, should be on the alert not to project modern customs, concepts, patterns of conduct or social structures, cross culturally on the ancient worlds in order to understand the texts against his own reconstructed picture.

On the other hand, it remains a question whether biblically reflected customs, concepts, structures or laws should be directly instituted in our modern society, just because they existed or are reflected in the biblical worlds. They may sound 'biblical' for the Bible reader, but they should not necessarily be transferred cross-culturally to all societies, or be applied directly onto us today. Should the liturgical dance of the Israelite cult or the return to house congregations of the New Testament church be a prerequisite for true worship? Should the death penalty be instituted and biblically authorized just because people were stoned or bloodvengence was practised in Israel? What should be taken over directly from the ancient worlds and what not? The answers to these questions remain the struggle of the Bible interpreter within his own context and circumstances, which he has to analyze and to consider.

A lack of knowledge of geography and expressions of the time, can also create distance and hamper the understanding of biblical texts. The Bible interpreter should acquaint him-/herself therefore with all the geographical information regarding biblical related countries and issues.

Another challenge confronting the interpreter is that of language. The biblical languages - Hebrew, Aramaic and Greek - are inaccessible to most people today. Since translation will always inevitably entail interpretation, and the level of interpretation is further determined by linguistic skills, background knowledge of culture and history, presuppositions and preunderstanding, the degree of the interpreter's education et cetera, Bible readers are dependent on specialist biblical scholars to provide them with several translations in their native tongue. Only when the ordinary Bible interpreter compares a few translations with each other, will he/she become aware of textual problems and come closer to understanding typical idioms and ancient expressions.

From the above description it is clear that biblical texts didn't fall from heaven. They can therefore not be understood mechanically. Neither were they dictated by God to earthly messengers, nor were they faxed through from a heavenly post office to mankind. These texts are the product of human processes in definite historical circum- 
stances and situations. The understanding process should take this in consideration. Discrepancies in biblical texts should therefore not result in the denial of contradictory accounts or in constructing harmonious explanations, since we know that the Bible being a book of faith - is not a scientific textbook or factual historical description. Facticity plays an inferior role to theological interpretation. Biblical authors would rather interpret historical facts theologically and are not interested in the correctness of facticity. Every text should thus be explained and understood within its own context(s) and background. Several examples can illustrate this. One can raise the questions: Who incited David to count the people? - God (2 Sam 24) or Satan (1 Chron 21); What caused the Reed sea to split during the exodus? Did Moses hit the water with his stick (Ex 14:16)? - Did he stretch out his hands over the water (Ex 14:21) or did God address the waters (Ps 106:9)? A last question: What happened to Judas? - Did he hang himself (Mt 27:5) or did he fall to his death and burst open (Acts 1:18). These accounts are contradictory. Explanations for the discrepancies though, can be saught in the historical, literary or theological context of every text.

The opportunity to determine the transmission processes, the different contexts, the historical background and the theological emphases of biblical texts thus remain some of the challenges confronting the Bible interpreter.

\section{ROLE OF THE BIBLE INTERPRETER}

The interpreter plays a crucial role in interpreting the Bible. Interpreters are people with their own personal circumstances and situations. No person can interpret in a vacuum. Each person has presuppositions and preunderstandings (Deist 1994:364). These presuppositions and preunderstandings are part of the interpreters interpreting equipment; they are the spectacles through which he reads, interprets and understands reality and also biblical texts. They are formed by the interpreters life setting: his environment, his education or lack thereof, his political and ideological convictions, the theological tradition which he follows, his denominational confession, his culture, selfimage and even his status in society.

No-one can interpret without certain prejudices or some preunderstanding of a subject or matter. It is quite understandable that someone who was abused by his/her father, would assign different semantic contents to the confession 'God is my father' than somebody else, who was loved and cared for by his/her father. It could take a lifetime's effort to convince the former that the confession is meant to express a loving God, who cares for people. If you could sneak into his world to get a glimpse of his preunderstanding of the concept 'father', you would understand his hermeneutics, although not necessarily agreeing with him. 
No-one should, however, approach interpretation with only preunderstanding. This results in a onesided interpretation where the interpreter becomes a captive of his own world and ideologies. To avoid this onesidedness, any Bible interpreter needs an awareness of his own presuppositions, prejudices and preunderstandings. He should recognize them and be aware of this limitation. If he is not aware of them, they should be revealed to him by his religious community or by the Bible interpreting society.

The devastating mistakes in biblical interpretation made by a vast majority of the South African society in the past, should caution biblical interpreters of this same society into questioning the intentions of all the so called biblically based statements, policies, laws and social arguments. This regards all aspects of society such as the political, social, moral, economic, religious and other spheres. Every interpreter should be subjected to the criticisms of the hermeneutical process. This will to some extent, limit onesided biblical interpretation in society, and will reveal the self-serving intentions of power-hungry individuals and groups who want to manipulate others with their so called 'biblical' and divinely authorized political, social or religious interpretations.

Interpreters do not interpret the Bible without purpose. Whether it is to strengthen the faith, to seek God's guidance in specific life situations, to create hope, to legitimize a viewpoint or to be comforted in a distressful situation, there is a purpose informing the act of interpretation. With these and even other aims interpreters read the biblical texts to create meaning for themselves or their community of faith.

\section{VARIED FORMS OF BIBLICAL LITERATURE}

A few remarks ha'e to be made regarding the kinds of literature through which the Bible manifests itself. People are often heard to say: 'I read and believe the Bible just as it stands'. This statement may sound very pious and godfearing, but it reveals ignorance of the possibility that Scripture speaks in various ways. To read the Bible just as it is, reveals a fundamentalistic attitude toward biblical interpretation, which does not take the literary context of the Bible seriously. Perhaps one of the most important hermeneutical keys to biblical understanding is the fact that the Bible consists of different literary types or genres. Each genre has its own set of rules for understanding. Apart from the macro-genres of poetry and prose, the biblical texts appear in several literary forms: These include the discourses of narrative, law, prophecy, wisdom literature, gospels, epistles, apocalyptic literature and several other sub-genres.

Literary genre is closely connected to specific life situations or Sitze im Leben. In identifying specific types of literature, specific life situations can be supposed and analyzed. By neglecting the literary genre of biblical texts, the interpreter tends to misunderstand the significance and theological emphases of these texts. 


\section{VARIOUS METHODOLOGICAL APPROACHES}

The process of interpretation requires a variety of hermeneutical approaches. The complexity of the understanding process, the variety of angles of incidence from which interpretation can be launched as well as the various literary forms which are employed in biblical texts, necessitate these different approaches (Goldingay 1995:13ff). Without intending to be comprehensive or elaborating on every hermeneutical model, some basic guidelines can be offered. The history of biblical interpretation with various methodological issues and approached has already been dealt with extensively by several scholars (Klein, Blomberg \& Hubbard 1993; Tate, 1991; Thiselton, 1992).

When the modern interpreter reads the biblical texts, he/she basically enters basically into three worlds of the hermeneutics: the world of the author, the world of the text and the world of the hearer/reader (very simplistically sketched). Initially the interpreter is a spectator, who perceives a communication process where an author sends a message through the medium of a text to a receiver. But soon he becomes a participant when he gets involved in the processes of understanding the various aspects regarding all three these worlds.

In order to understand the world behind the text, the world of the text, and the world before the text, various methods of approach are followed (West 1991:96ff). These can be reduced to the author centred methods, the text centred methods and the reader centred methods. Scholars sometimes characterize or divide them differently, but basically we are dealing with historical approaches, literary or structural approaches and lastly the post-structural or social scientific approaches.

Historical approaches regard the text as a product or creation of the human mind. Their intention is to discover the world of this mind and the historical circumstances within which this mind existed and operated. In this regard source criticism and redaction criticism contribute to the historical understanding of the text.

Literary approaches are concerned with the way a text works as well as its structure. The text is regarded as a literary artifact. It is a coherent and complete whole with intrinsic communicative signals in its structure (Lategan 1991:4). These structures and stylistic features are analyzed and their significance determined. Meaning is therefore not only found within the text itself, but also in relationship to the reader. Disciplines like structural criticism, narrative criticism, canonical criticism, rhetorical criticism and reader-response criticism participate here in the discovering of literary aspects in the text.

Post-structural approaches include several ways of reading a text. Only two eclectic exponents are mentioned here by way of illustration. Many more exist. Feminist criticism, for example, concentrates on the political, social and economic rights of the woman. It promotes a gendered perspective within such a hermeneutical mind. 
Deconstructive criticism on the other hand focuses on the dismantling of existing patterns and shows how broken and imperfect these organizing patterns are. This approach stresses the need to know the incompleteness of language and the structure of language. Fresh insight is made possible by the free play of the interpreter with a text. It thus stimulates the interpreter to alternative thinking.

With the awareness and understanding of these various hermeneutical angles which come into play with the interpretation of the Bible, ordinary biblical interpreters as well as the Christian community of the New South Africa will increasingly realize the complexity of the processes of biblical understanding, and the multi-dimensional aspect of human involvement.

\section{CONCLUSION}

For Christians in South Africa the Bible is still a book of faith. Because it represents the voice of God, heard through the numerous religious experiences of the past, Bible interpreters should treat this book with respect. In order to maintain responsible interpretation and to reject the misuse of biblical texts in the political, social, moral and religious spheres of the New South Africa, a few simple hermeneutical guidelines can be brought into consideration. Biblical interpreters should insist on them.

* People should realize the complexity of the processes involved in biblical understanding, and that the interpreter is confronted with several problems an challenges;

* the interpreter should recognize his own presuppositions, prejudices and preunderstandings and not refrain from revealing the presuppositions and prejudices of his society;

* the interpreter should identify the different kinds of biblical literature and acquaint him/herself with the hermeneutical rules for every literary genre;

* the interpreter should acquaint him/herself with the various methodological approaches to biblical texts.

By doing so, biblical interpreters can contribute to building a more tolerant and independent thinking Christian community of faith in South Africa. 


\section{Works consulted}

Barton, J 1984. Reading the Old Testament. London: Darton, Longman \& Todd.

Deist, F E 1994. Ervaring, rede en metode in Skrifuitleg. Pretoria: RGN Uitgewers.

Goldingay, J 1995. Models for interpretation of Scripture. Michigan: Eerdemans.

Kaiser, W C (Jr) \& Silva M 1994. An introduction to biblical hermeneutics. Michigan: Zondervan.

Klein, W, Blomberg, C L \& Hubbard, R L 1993. Introduction to biblical interpretation. Dallas: Word.

Lategan B L 1991. The challenge of contextuality. Scripture S9, 1-6.

McKenzie S L \& Haynes S R (Eds) 1993. To each its own meaning: An introduction to biblical critisisms and their application. Louisville: Westminister

Tate, W R 1991. Biblical interpretation: An integrated approach. Massachusetts: Hendrickson.

Thiselton, A C 1992. New horizons in hermeneutics. Michigan: Zondervan.

West, G O 1991. The relationship between different modes of reading (the Bible) and the ordinary reader. Scriptura S9, 87-110. 